DOC:

УДК 621.899:519.87

В.Д. Вернигора, к.т.н., доцент, vernyhora.viktor@gmail.com

О.М. Коробочка, д.т.н., професор, ekorobochra@ukr.net

Дніпровський державний технічний університет, м. Кам’янське

\title{
МАТЕМАТИЧНЕ МОДЕЛЮВАННЯ ПРОЦЕСУ ОЧИЩЕННЯ МИЮЧОГО РОЗЧИНУ НА МАСЛОВІДДІЛЬНИКУ БЕЗПЕРЕРВНОЇ ДІЇ
}

Запропоновано безреагентний метод очищення миючого розчину від масел і органічних речовин в замкненому контурі водообігу системи утилізації шліфувальних шламів на масловіддільнику безперервної дії. Отримана математична модель ступеня очищення миючого розчину від масла і органічних речовин. Визначено ефективні режимні параметри масловіддільника безперервної дії: середня швидкість руху забрудненого миючого розчину, вхідна кониентрація забруднення маслами та температура розчину.

Ключові слова: очищення; миючий розчин; масловіддільник; шліфувальний шлам; утилізачія; метод математичного моделювання експерименту.

A non-reagent method of cleaning a cleaning solution from oils and organic substances in a closed circuit of the water circulation system for grinding sludge utilization on a continuous oil separator is proposed. The mathematical model of purification cleaning solution degree from oil and organic substances was obtained. The effective mode parameters of the continuous-action oil separator were determined: average speed of contaminated detergent solution movement, inlet concentration of oil contamination and solution temperature.

Keywords: cleaning; cleaning solution; oil separator; grinding sludge; recycling; method of experiment mathematical modeling.

\section{Постановка проблеми}

В даний час надається чимале значення проблемам екологічної чистоти технологічних процесів і безвідходності виробництва. Впровадження маловідходних і безвідходних технологій експлуатації водних технологічних рідин і миючих розчинів в машинобудівному виробництві є актуальною проблемою.

Проблема накопичення промислових відходів має ряд серйозних екологічних і економічних аспектів і потребує прийняття заходів щодо ії вирішення. Низький обсяг переробки відходів (10-15\%) зумовлює зростання техногенного забруднення усіх компонентів навколишнього природного середовища: поверхневих і підземних вод, атмосферного повітря, геологічного середовища, а також сприяє зміні ландшафтів. Особливу проблему представляють шліфувальні шлами, які $\epsilon$ важко руйнівним конгломератом металевих частинок 3 вкрапленням абразиву $\mathrm{i}$ залишку мастильно-охолоджувальних рідин (МОР). Так, щорічно на підшипникових заводах утворюються до 10 тис. тон відходів шліфувальних шламів. На теперішній час вони в основному не перероблюються, а вивозяться на спеціальні захоронення або на звалища, погіршуючи екологію. У зв'язку із значним вмістом в шліфувальних шламових відходах неметалевих включень і технічних масел вони не можуть бути використані у якості вторинної сировини без попередньої переробки. Технології утилізації до теперішнього часу недосконало розвинуті для успішного впровадження у виробничих умовах.

Авторами [1] запропонована технологія утилізації шламів абразивної обробки металів, що дозволяє зменшити накопичення шламових відходів та підвищити екологічну безпеку навколишнього середовища. Однією з технологічних операцій процесу утилізації шламу в комплексній системі є миття. В процесі миття шламів абразивної обробки металів миючий водний розчин насичується маслом і органічними залишками водних МОР, що негативно впливає на роботу миючого обладнання і приводить до погіршення якості очищення твердих частинок шламу. 
При експлуатації миючого розчину на основі синтетичних миючих засобів відбувається утворення емульсій і суспензій, накопичення і утримування великого об'єму забруднень, головними з яких є нафтопродукти. У роботі [2] відмічено, що миючі розчини здатні накопичувати у своєму об'ємі синтетичні та напівсинтетичні масла від 17 до 19 г/л, а мінеральних — до 24 г/л. Миюча здатність розчину значно знижується при досягненні 20 г/л мінерального і 17 г/л синтетичного та напівсинтетичного забруднення.

Термін служби миючих розчинів складає від $1-2$ до $2-4$ тижнів. При довготривалому використанні забруднених миючих розчинів більш інтенсивно відбувається зношування обладнання комплексної системи екологічно безпечної технології утилізації шламів абразивної обробки металів, сопел форсунок, перекачуючих насосів та ущільнень. Забруднення, що накопичуються у баках розчину, зменшують корисний об'єм баків, що збільшує кратність перекачування розчинів і робить інтенсивнішим використання. Усе це веде до збільшення витрат на технічне обслуговування обладнання. Крім того, на 20-45 \% збільшуються витрати енергії на нагрів розчину, оскільки нагрівальні елементи баків розчину покриваються теплоізолюючим шаром, що суперечить вимогам по енергозбереженню на промислових підприємствах [3]. При великій забрудненості розчину збільшується прилипання масла до поверхні деталей, що очищаються. Емульсоване в розчині масло після випаровування розчину переходить на поверхню деталі. Для того щоб масло не забруднювало поверхню деталі до значень $0,10-0,35$ мг $/ \mathrm{cm}^{2}$, його концентрація в розчині повинна бути не більше $1,0-3,5$ г/л [3].

Для підвищення якості очищення твердих частинок шламу необхідно здійснювати безперервне очищення забрудненого миючого розчину. Миючий розчин потрібно очищати тільки від масла і залишків МОР без зміни іонного складу води в замкненому контурі водообігу. Це дозволить зберегти миючу здатність розчину та повернути його у виробничий процес, чим забезпечується збільшення терміну експлуатації і відпадає необхідність в його утилізації. Для вирішення поставленої задачі в роботі [1] запропонований безреагентний спосіб очищення забрудненого миючого розчину від масел і МОР за допомогою масловіддільника безперервної дії [4]. Масловіддільник безперервної дії повинен забезпечувати ступінь очищення миючого розчину, щоб концентрація масел в розчині не перевищувала 1,0-3,5 г/л, чим буде забезпечена продуктивність комплексної системи утилізації шламів.

\section{Аналіз останніх досліджень і публікацій}

Для очищення миючих розчинів від масел і органічних речовин на промислових виробництвах України і закордонних держав використовують механічний, фізико-хімічний, хімічний та біологічний методи.

Для цього можуть бути використані широко вживані для очищення масловмісних стічних вод реагентні методи. Одним з таких методів є очищення води за допомогою бентонітової глини, який включає в себе поєднання хімічних процесів разом із фізичними, що робить процес водоочищення ефективнішим $[5,6]$. Існуючі нині технології регенерації відпрацьованих масел 3 використанням кислот, лугів, відбілюючих глин, як правило, складні, багатозатратні і екологічно небезпечні. При такій регенерації разом із забрудненнями видаляються й присадки, що не дозволяє повторно використовувати масла по прямому призначенню.

У роботі [7] відмічено, що фізико-механічне локальне очищення, як правило, не дає очікуваних результатів і не забезпечує підготовку стічних вод до повного біологічного очищення, особливо тоді, коли мова йде про висококонцентровані стоки, в яких присутні складні полідисперсні системи з колоїдів та розчинених органічних речовин. Для очищення високоцентрованих стічних вод на заміну загальноприйнятим методам механічного, біологічного й фізикохімічного очищення у роботі [7] пропонується застосовувати електрокоагуляцію та електрофлотацію. Але застосування даних методів суттєво впливає на вартість кінцевої продукції, тому що необхідне застосування складних технологічних схем, дорогих реагентів та флокулянтів, енергомістких та громіздких споруд.

Для миючих розчинів застосовують триступінчасте очищення [8]. На першому ступеню миючий розчин проходить відстійник-нафтовловлювач, де очищається від неемульгованих мастил і зважених речовин; на другому - електрокоагулятор-електрофлотатор, в якому відбувається руйнування емульсій і відділення масла. Концентрація масла знижується до 50 мг/л, 
зважених речовин - до 20 мг/л. На третьому ступеню очищення миючих розчинів використовуються сепаратори або фільтри, після чого вміст масел не перевищує 20 мг/л і розчин може бути повернений у виробництво. В якості матеріалу, що фільтрує, можна використовувати дерев'яну стружку, яка у міру забруднення спалюється, гранульований поліетилен високого тиску, очищений кварцовий пісок, волокнисті матеріали. Проте таке очищення має і свої недоліки. Утворюється велика кількість погано зневодненого осаду і виникає проблема його утилізації, унеможливлюється регенерація масла.

Автори роботи [9] надають перевагу флотації, що забезпечує безперервність і велику швидкість процесу, високу ступінь очищення (95-98 \%), можливість рекуперації вилучених речовин, простота конструкції флотаційних установок, незначні капіталовкладення. Недоліком такої технології є підвищені витрати електричної енергії, тому практичне використання перспективне лише для невеликих об'єктів [10, 11].

Проведений аналіз літературних джерел [5-11] показав, що дослідження проблеми очищення миючих розчинів (для металооброблювальної галузі) у наш час $є$ надзвичайно важливим і актуальним, а розробки в даному напрямку — перспективними і заслуговують детального вивчення.

\section{Формулювання мети дослідження}

Метою даної роботи $є$ моделювання процесу очищення миючого розчину від масла і залишків МОР на масловіддільнику безперервної дії. Це дає можливість визначити режимні параметри масловіддільника: середню швидкість забрудненого миючого розчину, вхідну концентрація забруднення розчину маслами та температуру. Визначені параметри дозволять проводити очищення миючого розчину, при яких концентрація масел в очищеному розчині не буде перевищувати $1,0-3,5$ г/л. Це дозволить зберегти миючу здатність розчину та повернути його у виробничий процес, чим забезпечується збільшення терміну експлуатації і відпадає необхідність в його утилізації.

Для досягнення поставленої мети вирішувалися наступні задачі:

- розробити математичну модель процесу очищення миючого розчину від масла і залишків МОР на масловіддільнику безперервної дії;

- визначити режимні параметри масловіддільника: середню швидкість забрудненого миючого розчину, вхідну концентрацію забруднення розчину маслами та температуру.

\section{Виклад основного матеріалу}

В замкнених водозворотних системах експлуатації водних миючих розчинів основною проблемою $є$ забезпечення простійної продуктивності процесу очищення розчину від забруднення. Для забезпечення постійної продуктивності процесу необхідно визначити ступінь очищення миючого розчину від масла і МОР за допомогою масловіддільника безперервної дії при різних режимних параметрах його роботи.

Поставлене завдання вирішувалися знаходженням умовного мінімуму функції відгуку для ступеню очищення шляхом використання методу математичного моделювання експерименту. Для одержання зазначеної функції проведений аналіз експериментальних даних процесу масловідділення. Дослідження впливу режимних параметрів масловіддільника безперервної дії на ступінь очищення $C_{o \varphi}=f\left(v_{c e p}, k_{B x}, T\right)$ миючого розчину від масла виконувалося в наступних інтервалах:

- середня швидкість забрудненого миючого розчину $v_{c e p}$, л/с, 3 метою запобігання турбулізації потоку руху рідини внаслідок конструкції масловіддільника, варіювалась у діапазоні від $0,006 \mathrm{~m} / \mathrm{c}$ до $0,012 \mathrm{~m} / \mathrm{c}$;

- вхідна концентрація забруднення розчину маслами $k_{6 x}$, г/л, варіювалась у діапазоні від 5 до 15 г/л (на підставі статистичних даних дослідження забруднення рідини у промислових умовах);

- температура розчину $T$, ${ }^{\circ} \mathrm{C}$, варіювалась у діапазоні від $20{ }^{\circ} \mathrm{C}$ до $60{ }^{\circ} \mathrm{C}$. Тому що, при температурі менше $20{ }^{\circ} \mathrm{C}$ в'язкість масла збільшується і негативно впливає на процес масловідділення. 3 підвищенням температури понад $60^{\circ} \mathrm{C}$ підвищується інтенсивність випаровування миючого розчину. 
Для побудови математичної моделі залежності ступеня очищення від вищенаведених факторів у вигляді ступеневого поліному другого порядку реалізований центральний композиційний ротатабельний план другого порядку для трьох факторів. Рівні варіювання факторів представлені у табл. 1.

Таблиия 1. Рівні та інтервали варіювання факторів

\begin{tabular}{|c|c|c|c|c|c|c|c|c|}
\hline \multirow[b]{2}{*}{$\begin{array}{l}\text { № } \\
\text { до- } \\
\text { слід. }\end{array}$} & \multirow[b]{2}{*}{ Фактори } & \multirow[b]{2}{*}{$\begin{array}{l}\text { Кодове } \\
\text { позна- } \\
\text { чення }\end{array}$} & \multirow{2}{*}{$\begin{array}{c}\text { Інтер- } \\
\text { вали } \\
\text { варію- } \\
\text { вання }\end{array}$} & \multicolumn{5}{|c|}{ Рівні факторів } \\
\hline & & & & $-1,682$ & -1 & 0 & +1 & $+1,682$ \\
\hline 1 & $\begin{array}{l}\text { Середня швидкість забруд- } \\
\text { неної рідини } \\
v_{\text {сер }} \cdot 10^{-3}, \text { м } / \mathrm{c}\end{array}$ & $\mathrm{x}_{1}$ & 3 & 4 & 6 & 9 & 12 & 14 \\
\hline 2 & $\begin{array}{l}\text { Вхідна концентрація за- } \\
\text { бруднення маслами } \\
k_{\text {вx }}, \text { г/л }\end{array}$ & $\mathrm{x}_{2}$ & 5 & 2 & 5 & 10 & 15 & 18 \\
\hline 3 & $\begin{array}{l}\text { Температура водної техно- } \\
\text { логічної рідини } T,{ }^{\circ} \mathrm{C}\end{array}$ & $\mathrm{x}_{3}$ & 20 & 6 & 20 & 40 & 60 & 74 \\
\hline
\end{tabular}

Загальна кількість досліджень у матриці центрального композиційного ротатабельного плану при $\kappa=3$ факторах склала [12]:

$$
N=2^{\kappa}+2 \kappa+n_{0}=2^{3}+2 \cdot 3+6=20,
$$

де $n_{0}$ - кількість експериментів в центрі плану з нульовими координатами.

По результатам досліджень, виконаних у відповідності з прийнятим планом експерименту, можна оцінити коефіцієнти рівняння регресії виду:

$$
y_{p}=b_{0}+b_{1} x_{1}+b_{2} x_{2}+b_{3} x_{3}+b_{12} x_{1} x_{2}+b_{13} x_{1} x_{3}+b_{23} x_{2} x_{3}+b_{11} x_{1}^{2}+b_{22} x_{2}^{2}+b_{33} x_{3}^{2} .
$$

Матриця планування і результати дослідження наведені у табл. 2 .

При кількості факторів $\kappa=3$ коефіцієнти рівняння регресії (2), які розраховано за формулами [12], становлять:

$$
\begin{aligned}
& b_{0}=1,516 ; \quad b_{1}=0,216 ; \quad b_{2}=0,133 ; \quad b_{3}=-0,14 ; \\
& b_{12}=-0,06 ; \quad b_{13}=-0,07 ; \quad b_{23}=0,045 \text {; } \\
& b_{11}=-0,05 ; \quad b_{22}=0,062 ; \quad b_{33}=0,103 \text {. }
\end{aligned}
$$

Дисперсію $s_{y}^{2}$ відтворюваності визначаємо по результатам досліджень в центрі плану (табл. 3).

Дисперсії, що характеризують помилки в визначенні коефіцієнтів рівняння регресії, згідно [12] при $\kappa=3$ становлять:

$$
\begin{aligned}
& S^{2}\left\{b_{0}\right\}=0,0000024 ; S^{2}\left\{b_{i}\right\}=0,000001 ; \\
& S^{2}\left\{b_{i l}\right\}=0,0000018 ; S^{2}\left\{b_{i i}\right\}=0,000001 .
\end{aligned}
$$

Довірчі інтервали для коефіцієнтів рівняння регресії (2):

$$
\begin{aligned}
& \Delta b_{0}= \pm t \cdot S\left\{b_{0}\right\}= \pm 0,0039 ; \\
& \Delta b_{i}= \pm t \cdot S\left\{b_{i}\right\}= \pm 0,0026 ; \\
& \Delta b_{i l}= \pm t \cdot S\left\{b_{i l}\right\}= \pm 0,0034 ; \\
& \Delta b_{i i}= \pm t \cdot S\left\{b_{i i}\right\}= \pm 0,0026,
\end{aligned}
$$

де $\pm t=2,57$ - табличне значення критерію Ст'юдента при $5 \%$-му рівні значимості і числом ступеню свободи $f=5$. 
Таблиця 2. Матриця планування і результати дослідження

\begin{tabular}{|c|c|c|c|c|c|c|c|c|c|c|c|c|c|}
\hline $\begin{array}{c}\text { № } \\
\text { до- } \\
\text { слі- } \\
\text { ду }\end{array}$ & $x_{0}$ & $x_{1}$ & $x_{2}$ & $x_{3}$ & $x_{1} x_{2}$ & $x_{1} x_{3}$ & $x_{2} x_{3}$ & $x^{2}{ }_{1}$ & $x_{2}{ }_{2}$ & $x^{2}{ }_{3}$ & $y_{\text {дслл }}$ & $y_{p}$ & $\begin{array}{c}\text { По- } \\
\text { хиб- } \\
\text { ка, } \\
\%\end{array}$ \\
\hline 1 & 1 & 1 & 1 & 1 & 1 & 1 & 1 & 1 & 1 & 1 & 1,754 & 1,756 & 0,10 \\
\hline 2 & 1 & 1 & 1 & -1 & 1 & -1 & -1 & 1 & 1 & 1 & 2,093 & 2,096 & 0,10 \\
\hline 3 & 1 & 1 & -1 & 1 & -1 & 1 & -1 & 1 & 1 & 1 & 1,506 & 1,511 & 0,34 \\
\hline 4 & 1 & 1 & -1 & -1 & -1 & -1 & 1 & 1 & 1 & 1 & 2,032 & 2,033 & 0,03 \\
\hline 5 & 1 & -1 & 1 & 1 & -1 & -1 & 1 & 1 & 1 & 1 & 1,578 & 1,581 & 0,2 \\
\hline 6 & 1 & -1 & 1 & -1 & -1 & 1 & -1 & 1 & 1 & 1 & 1,632 & 1,631 & 0,08 \\
\hline 7 & 1 & -1 & -1 & 1 & 1 & -1 & -1 & 1 & 1 & 1 & 1,118 & 1,113 & 0,04 \\
\hline 8 & 1 & -1 & -1 & -1 & 1 & 1 & 1 & 1 & 1 & 1 & 1,342 & 1,344 & 0,16 \\
\hline 9 & 1 & 1,68 & 0 & 0 & 0 & 0 & 0 & 2,83 & 0 & 0 & 1,746 & 1,743 & 0,14 \\
\hline 10 & 1 & $-1,68$ & 0 & 0 & 0 & 0 & 0 & 2,83 & 0 & 0 & 1,016 & 1,017 & 0,13 \\
\hline 11 & 1 & 0 & 1,68 & 0 & 0 & 0 & 0 & 0 & 2,83 & 0 & 1,916 & 1,916 & 0,01 \\
\hline 12 & 1 & 0 & $-1,68$ & 0 & 0 & 0 & 0 & 0 & 2,83 & 0 & 1,473 & 1,469 & 0,05 \\
\hline 13 & 1 & 0 & 0 & 1,68 & 0 & 0 & 0 & 0 & 0 & 2,83 & 1,568 & 1,566 & 0,12 \\
\hline 14 & 1 & 0 & 0 & $-1,68$ & 0 & 0 & 0 & 0 & 0 & 2,83 & 2,045 & 2,047 & 0,08 \\
\hline 15 & 1 & 0 & 0 & 0 & 0 & 0 & 0 & 0 & 0 & 0 & 1,520 & 1,516 & 0,26 \\
\hline 16 & 1 & 0 & 0 & 0 & 0 & 0 & 0 & 0 & 0 & 0 & 1,514 & 1,516 & 0,08 \\
\hline 17 & 1 & 0 & 0 & 0 & 0 & 0 & 0 & 0 & 0 & 0 & 1,516 & 1,516 & 0 \\
\hline 18 & 1 & 0 & 0 & 0 & 0 & 0 & 0 & 0 & 0 & 0 & 1,520 & 1,516 & 0,026 \\
\hline 19 & 1 & 0 & 0 & 0 & 0 & 0 & 0 & 0 & 0 & 0 & 1,514 & 1,516 & 0,08 \\
\hline 20 & 1 & 0 & 0 & 0 & 0 & 0 & 0 & 0 & 0 & 0 & 1,510 & 1,516 & 0,4 \\
\hline
\end{tabular}

Таблиия 3. Розрахунок дисперсії відтворюваності $s_{y}^{2}$

\begin{tabular}{|c|c|c|c|c|c|}
\hline $\begin{array}{c}\text { № } \\
\text { дослід. }\end{array}$ & $y_{j}$ & $\bar{y}_{j}$ & $y_{j}-\bar{y}_{j}$ & $\left(y_{j}-\bar{y}_{j}\right)^{2}$ & $s_{y}^{2}$ \\
\hline 15 & 1,520 & \multirow{6}{*}{$\begin{array}{l}\bar{y}=\frac{\sum_{z=1}^{n_{0}} y_{z}}{n_{0}}= \\
=\frac{9,094}{6}= \\
=1,516\end{array}$} & 0,004 & 0,000016 & \multirow{7}{*}{$\begin{array}{l}s_{y}^{2}=\frac{\sum_{j=1}^{n_{0}}\left(y_{j}-\bar{y}_{j}\right)^{2}}{n_{0}-1} \\
=\frac{0,000076}{5}= \\
=0,0000152\end{array}$} \\
\hline 16 & 1,514 & & $-0,002$ & 0,000004 & \\
\hline 17 & 1,516 & & 0 & 0 & \\
\hline 18 & 1,520 & & 0,004 & 0,000016 & \\
\hline 19 & 1,514 & & $-0,002$ & 0,000004 & \\
\hline 20 & 1,510 & & $-0,006$ & 0,000036 & \\
\hline - & $\begin{array}{l}\sum_{j=1}^{n_{0}} y_{j}= \\
=9,094\end{array}$ & - & - & $\begin{array}{l}s_{E}=\sum_{j=1}^{n_{0}}\left(y_{j}-\bar{y}_{j}\right)^{2}= \\
=0,000076\end{array}$ & \\
\hline
\end{tabular}


При перевірці коефіцієнтів регресії за критерієм Ст'юдента (при 5 \%-му рівні значимості та числі ступеню свободи $f=5$ ) встановлено, що усі коефіцієнти більше довірчого інтервалу, тому вони $\epsilon$ значимими і включені до рівняння регресії (2).

В результаті рівняння регресії (2) буде мати вид:

$$
\begin{aligned}
& y_{p}=1,516+0,216 x_{1}+0,133 x_{2}-0,14 x_{3}-0,06 x_{1} x_{2}-0,07 x_{1} x_{3}+ \\
& +0,045 x_{2} x_{3}-0,05 x_{11}^{2}+0,062 x_{22}^{2}+0,1 x_{33}^{2}
\end{aligned}
$$

Перевірка гіпотези адекватності моделі (5) за критерієм Фішера при $5 \%$-му рівні значущості і числах ступенів свободи дисперсії адекватності $f_{a d}=N-k-\left(n_{0}-1\right)=20-10-(6-1)$ $=5$ і дисперсії відтворюваності $f_{y}=n_{0}-1=6-1=5$ показала, що отримана модель адекватна, оскільки розрахункове значення критерію менше табличного $F_{p}=1,72<F_{T}(0,05 ; 5 ; 5)=5,1$ [13].

Обчислені за рівнянням (5) значення відрізняються від експериментальних на величини, що не перевищують похибку дослідження (табл. 2).

Кодовані значення факторів пов'язані з натуральними наступними залежностями:

$$
\begin{gathered}
x_{1}=\frac{v_{c e p}-0,009}{0,003}=333,3 v_{c e p}-3 ; \\
x_{2}=\frac{K_{b x}-10}{5}=0,2 k_{B x}-2 ; \\
x_{3}=\frac{T-40}{20}=0,05 T-2 .
\end{gathered}
$$

Тоді рівняння (5) з урахуванням залежностей (6) буде мати вигляд:

$$
\begin{aligned}
& C_{o y}=0,49+260 v_{c e p}-0,006 k_{B x}-0,021 T-4 v_{c e p} k_{B x}-1,169 v_{c e p} T+ \\
& +0,0005 k_{B x} T-5554,45 v_{c e p}^{2}+0,0024 k_{B x}^{2}+0,00025 T^{2}
\end{aligned}
$$

Рівняння (7) адекватно, тому його можна використовувати як інтерполяційну формулу для обчислення величини $C_{\text {оч}}$, г/л - ступеню очищення миючого розчину від масла.

За результатами розрахунків за рівнянням (7) були побудовані графіки (рис. 1-3) залежності ступеню очищення $C_{\text {оч }}$ від середньої швидкості забрудненої рідини $v_{c e p}$, вхідної концентрації забруднення маслами $k_{6 x}$ та температури рідини $T$.
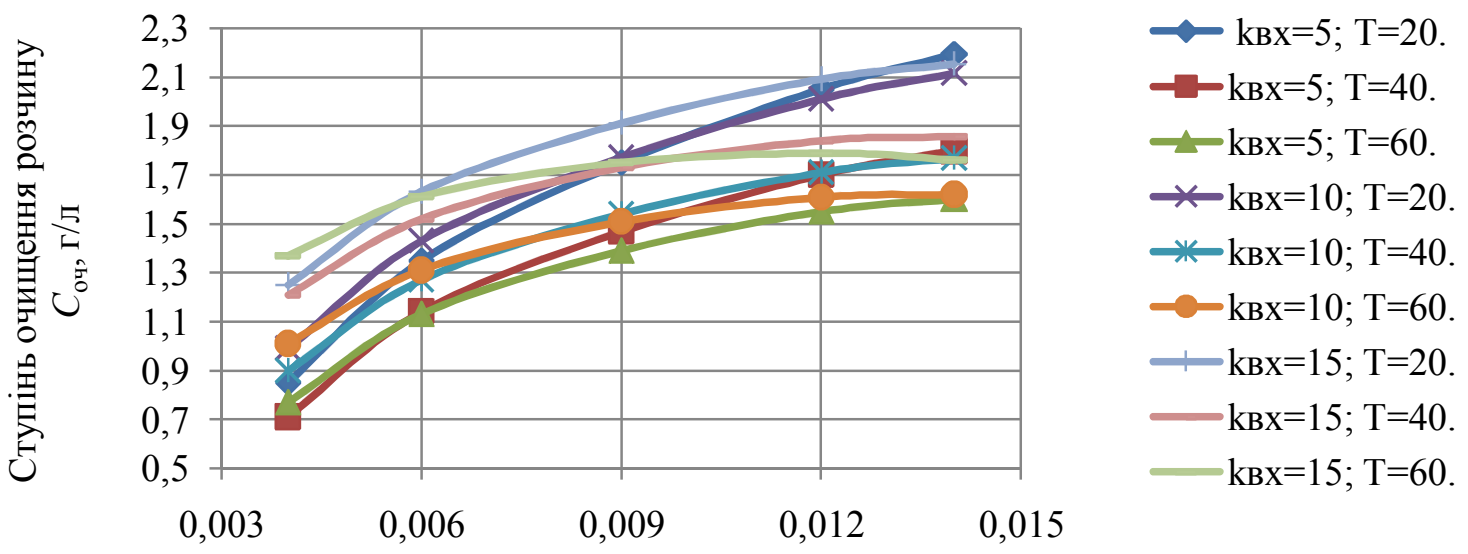

Середня швидкість забрудненого розчину $v_{\text {сер }}, \mathrm{m} / \mathrm{c}$

Puc. 1. Залежність ступеня очищення $C_{\text {оч }}$ від середньої швидкості забрудненої рідини $v_{\text {сер }}$ 


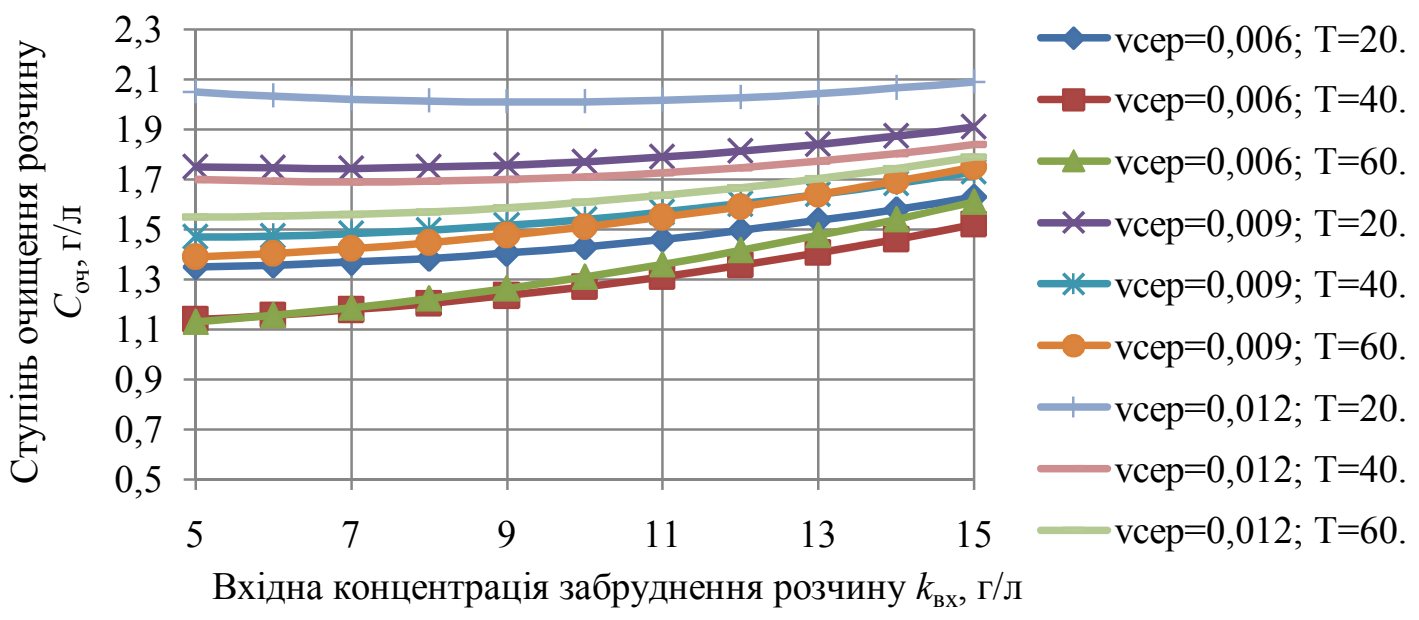

Puc. 2. Залежність ступеня очищення $C_{о ч}$ від вхідної концентрації забруднення рідини $k_{8 x}$
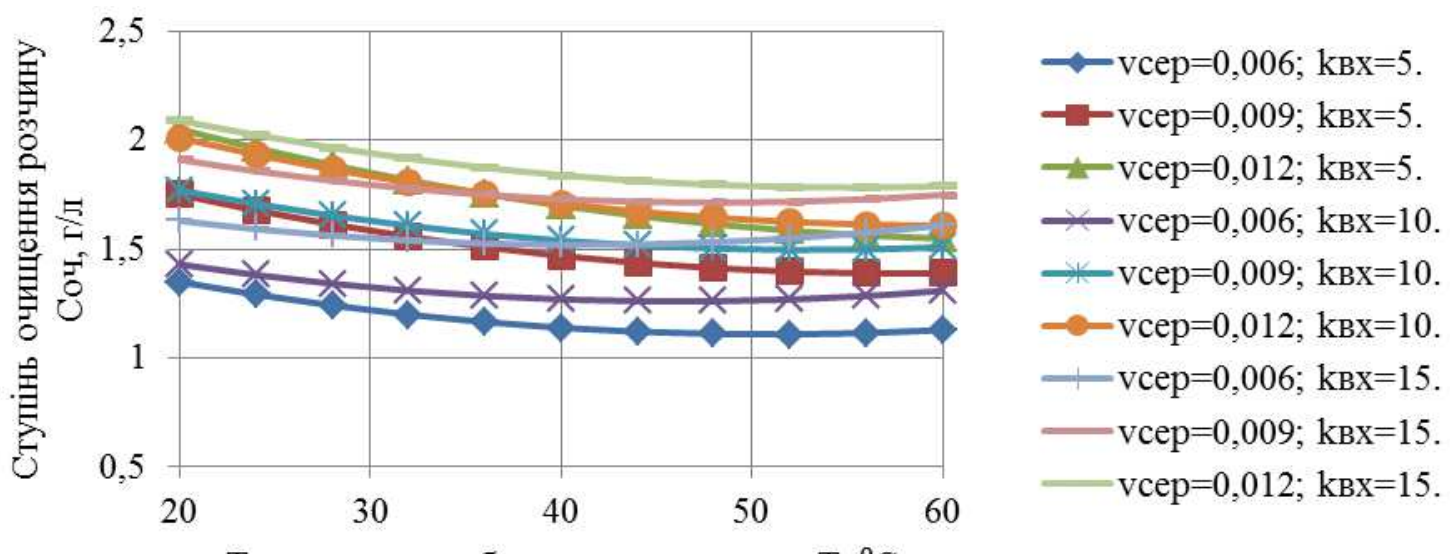

Температура забрудненого розчину $\mathrm{T},{ }^{\circ} \mathrm{C}$

Puc. 3. Залежність ступеня очищення $C_{о ч}$ від температури рідини $T$

Використання математичної залежності дає можливість підвищити ефективність процесу масловідділення шляхом розрахунку раціональних режимних параметрів, при яких концентрація масел в очищеному миючому розчині не буде перевищувати $1,0-3,5$ г/л.

Досягнення заданого ступеню очищення розчину від масла і органічних речовин можливо шляхом призначення режимних параметрів, комбінацію яких можна визначити з графіків (рис. $1-3)$ :

- залежність ступеню очищення $C_{\text {оч }}$ від середньої швидкості забрудненої рідини $v_{c e p},(\pi / \mathrm{c})$ при заданих значеннях двох інших параметрів: вхідної концентрації забруднення маслами $k_{8 x}(5,10,15$ г/л) і температури рідини $T\left(20,40,60^{\circ} \mathrm{C}\right)$ (рис. 1$)$;

- залежність ступеню очищення $C_{o ч}$ від вхідної концентрації забруднення маслами $k_{\theta x}$ при заданих значеннях двох інших параметрів: середньої швидкості рідини $v_{c e p}(0,006,0,009$, 0,012 л/с) і температури рідини $T\left(20,40,60^{\circ} \mathrm{C}\right)$ (рис. 2$)$;

- залежність ступеню очищення $C_{о ч}$ від температури рідини $T$ при заданих значеннях двох інших параметрів: середньої швидкості рідини $v_{\text {сер }}(0,006,0,009,0,012$ л/с) і вхідної концентрації забруднення маслами $k_{в x}(5,10,15$ г/л) (рис. 3$)$.

Встановлено, що концентрація масел в очищеному миючому розчині при роботі масловіддільника безперервної дії при встановлених режимних параметрах: середній швидкості рідини $v_{c e p}\left(0,006,0,009,0,012\right.$ л/с), вхідній концентрації забруднення маслами $k_{6 x}(5,10,15$ г/л) і те- 
мпературі рідини $T\left(20,40,60^{\circ} \mathrm{C}\right)$ не буде перевищувати 2,5 г/л. Відповідно чого збільшується продуктивність утилізації шліфувальних шламів і зменшуються витрати на приготування нового і утилізацію відпрацьованого миючого розчину.

\section{Висновки}

1. Отримано математичну модель процесу очищення миючого розчину від масла і залишків МОР на масловіддільнику безперервної дії. Математична модель адекватна, оскільки розрахункове значення критерію Фішера менше табличного $F_{p}<F_{T}=3,2$. Для ії розв'язання використовувалися метод математичного моделювання експерименту.

2. Отримані режимні параметри масловіддільника: середня швидкість руху забрудненого миючого розчину, вхідна концентрація забруднення розчину маслами та температура, які забезпечують ступінь очищення миючого розчину до концентрації в ньому забруднення в межах 1,0-3,5 г/л. Це дозволяє збільшити час працездатності миючого розчину, зменшити енерговитрати на його приготування і заміну, збільшити продуктивність утилізації шліфувальних шламів.

\section{Список використаної література}

1. Вернигора, В. Д., Коробочка, А. Н. (2008). Извлечение металлических частиц из шламов абразивной обработки металлов. Збагачення корисних копалин, 32 (73), 26-32.

2. Фокин О. И. Совершенствование технологи регенерации моющих растворов на предприятиях технического сервиса агропромышленного комплекса: автореф. дис. на здобуття наук. ступ. канд. техн. наук: 05.20.03. ФГОУ ВПО МГАУ им. В. П. Горячкина. Москва, 2009. 19 с.

3. Мажугин Е. И., Л. Казаков, Пашкевич А. В. Центробежная очистка моющих растворов при ремонте сельскохозяйственной техники: монограф. Горки: БГСХА, 2015. 185 с.

4. Масловіддільник безперервної дії: пат. 135726 Україна:МПК С02F1/40 (2006.01). № u 2019 01621; заявл.18.02.2019; опубл. 10.07.2019, Бюл. №13. 4 с.

5. Петрусь Р., Мальований М., Варчол Й., Одноріг 3., Петрушка І., Леськів Г. Технології очищення стоків із застосуванням природних дисперсних сорбентів. Хімічна промисловість України. 2003. № 2(55), С. 20-22.

6. Угляр Ю. М., Борщишин І. Д., Хром'як У. В. Електрофлотокоагуляційне очищення стічних вод підприємства ТОВ «Коломийський м'ясокомбінат». Восточно-Европейский журнал передовых технологий. 2014. Том 2, № 10(68). C. 30 - 34. DOI: https://doi.org/10.15587/17294061.2014.22986

7. Свиридов В. В., Свиридов А. В., Никифоров А.Ф. Физико-химические основы процессов микрофлотации. Екатеринбург: ГОУ ВПО УГЛТУ : ГОУ ВПО УГТУ-УПИ, 2006. 578 с.

8. Комарова Л. Ф., Полетаева М. А. Использование воды на предприятиях и очистка сточных вод в различных отраслях промышленности: уч. пособие. Барнаул: АлтГТУ, 2010. 174 с.

9. Аветісян Ю. І., Копаниця Ю. Д., Аргатенко Т. В. Оптимальне управління флотаційним блоком комплексу знежирення стічних вод жирового комбінату // Проблеми водопостачання, водовідведення та гідравліки. 2009. № 12. С. 78-88.

10. Пирузян А. В., Боковикова Т. Н., Найденов Ю. В. Эффективные методы очистки сточных вод мясоперерабатывающих предприятий. Фундаментальные и прикладные аспекты создания биосферно-совместимых систем: матер. Междунар. научн. - техн. интернет-конфер. Краснодар: Кубанский государственный технический университет, 2008.

11. Храменков С. В. Данилович Д. А. Предварительная очистка концентрированных сточных вод предприятий пищевой промышленности // Водоснабжение и санитарная техника: ВСТ. 2006. № 1. Ч. 2. С. $28-32$.

12. Спиридонов А. А. Планирование эксперимента при исследовании технологических процессов. М.: Машиностроение, 1981. 184 с.

13. Адлер Ю. П. Введение в планирование эксперимента. М.: Металлургия, 1979. 145 с. 


\title{
MATHEMATICAL MODELING OF THE WASHING SOLUTION CLEANING PROCESS ON CONTINUOUS ACTION OIL SEPARATORS Vernyhora V., Korobochka A.
}

\begin{abstract}
The problem of industrial waste accumulation has a number of serious environmental and economic aspects and requires action to be taken to discourse it. A particular problem is grinding sludge, which are a difficult destructive conglomerate of metallic particles with the introduction of abrasives and residual lubricants. Due to the high content of non-metallic inclusions and oils in the grinding sludge waste, they cannot be used as secondary raw materials without preliminary processing.

With high contamination of the solution, the adherence of the oil to the surface of the solid particles of sludge increases which is cleaned. Emulsified in solution the oil after its evaporation passes to the surface of the particles. In order that the oil does not contaminate the surface of the particles to values of $0.10-0-35 \mathrm{mg} / \mathrm{cm}^{2}$, its concentration in the solution should be no more than $1.0-3.5 \mathrm{~g} / \mathrm{l}$.

To ensure continuous process presentation, it is necessary to determine the degree of purification of the washing solution of oil and cooling liquids by means of a continuous separator oil separator at different operating parameters of its operation. The problem was solved by finding the conditional minimum of the response function for the degree of purification by using the method of mathematical modeling. To obtain this function, the experimental data of the oil separation process were analyzed. In the mathematical formulation of the problem, the following factors are taken as variables: the average velocity of the contaminated washing solution $v_{c e p}, 1 / \mathrm{s}$; input concentration of solution contamination with oils $k_{B x}, \mathrm{~g} / \mathrm{l}$; the temperature of solution $T,{ }^{\circ} \mathrm{C}$.

To construct a mathematical model of the dependence of the degree of the washing solution

purification $C_{O \Psi}=f\left(v_{c e p}, k_{B x}, T\right)(\mathrm{g} / \mathrm{l})$, namely, what is the concentration of oils in the purified washing solution from the above factors, the technique of experiment planning is used. To obtain the response function in the form of a second-order step polynomial, a second-order composite rotatable plan for three factors is implemented.

A mathematical model of the process of cleaning the cleaning solution of oils and organic substances is developed; it is possible to determine the concentration of contamination in the purified cleaning solution with the set mode parameters of the continuous action oil separator.
\end{abstract}

\section{References}

[1] Vernigora, V. D., Korobochka, A. N. (2008). Izvlechenie metallicheskih chastits iz shlamov abrazivnoy obrabotki metallov. Zbahachennia korysnykh kopalyn, 32 (73), 26-32.

[2] Fokin O. I. (2009). Sovershenstvovanie tekhnologi regeneracii moyushchih rastvorov na predpriyatiyah tekhnicheskogo servisa agropromyshlennogo kompleksa: avtoref. dis. na zdobuttya nauk. stupenya kand. tekhn. nauk: 05.20.03. FGOU VPO MGAU im. V. P. Goryachkina. Moskva, $19 \mathrm{~s}$.

[3] Mazhugin E. I., L. Kazakov, Pashkevich A. V. (2015). Centrobezhnaya ochistka moyushchih rastvorov pri remonte sel'skohozyajstvennoj tekhniki: monografiya. Gorki : BGSKHA, $185 \mathrm{~s}$.

[4] Masloviddilnyk bezperervnoi dii: pat. 135726 Ukraina: MPK C02F1/40 (2006.01). \# u 2019 01621; zaiavl. 18.02.2019; opubl. 10.07.2019, Biul. \# 20. 4 s.

[5] Petrus R., Malovanyi M., Varchol Y., Odnorih Z., Petrushka I., Leskiv H. (2003). Tekhnolohii ochyshchennia stokiv iz zastosuvanniam pryrodnykh dyspersnykh sorbentiv. Khimichna promyslovist Ukrainy, 2(55), 20-22.

[6] Uhliar Yu. M., Borshchyshyn I. D., Khromiak U. V. (2014). Elektroflotokoahuliatsiine ochyshchennia stichnykh vod pidpryiemstva TOV «Kolomyiskyi miasokombinat». VostochnoEvropeiskyi zhurnal peredovыkh tekhnolohyi. Tom 2, 10(68). 30-34. DOI: https://doi.org/10.15587/1729-4061.2014.22986 
[7] Sviridov V. V., Sviridov A. V., Nikiforov A.F. (2006) Fiziko-himicheskie osnovyi protsessov mikroflotatsii. Ekaterinburg: GOU VPO UGLTU : GOU VPO UGTU-UPI, 578.

[8] Komarova L. F., Poletaeva M. A. (2010). Ispolzovanie vodyi na predpriyatiyah i ochistka stochnyih vod v razlichnyih otraslyah promyishlennosti: uchebnoe posobie. Barnaul : AltGTU, 174.

[9] Avetisian Yu. I., Kopanytsia Yu. D., Arhatenko T. V. (2009). Optymalne upravlinnia flotatsiinym blokom kompleksu znezhyrennia stichnykh vod zhyrovoho kombinatu // Problemy vodopostachannia, vodovidvedennia ta hidravliky, 2009. 12. 78-88.

[10 Piruzyan A. V., Bokovikova T. N., Naydenov Yu. V. (2008). Effektivnyie metodyi ochistki stochnyih vod myasopererabatyivayuschih predpriyatiy. Fundamentalnyie i prikladnyie aspektyi sozdaniya biosferno-sovmestimyih sistem : mater. Mezhdunar. nauchn.--tehn. internet-konfer. Krasnodar : Kubanskiy gosudarstvennyiy tehnicheskiy universitet.

[11] Hramenkov S. V. Danilovich D. A. (2006). Predvaritelnaya ochistka kontsentrirovannyih stochnyih vod predpriyatiy pischevoy promyishlennosti // Vodosnabzhenie i sanitarnaya tehnika : VST, 1. Ch. 2. 28-32.

[12] Spiridonov A. A. (1981). Experiment planning in process research. M.: Mechanical engineering. $184 \mathrm{~s}$.

[13] Adler Yu. P. (1979). Introduction to experiment planning. M.: Metallurgy. 145 s. 